\title{
MATLAB (SimSCAPE) SimULATION AND EXPERIMENTAL VALIDATION OF SOLAR Photovoltaic System For Performance ANALYSIS UNDER VARYING ENVIRONMENTAL AND MISMATCH CONDITION
}

\author{
Deepak Verma ${ }^{1}$, S. Nema ${ }^{2}$, A. M. Shandilya ${ }^{3}$, Soubhagya K. Dash ${ }^{4}$ \\ Department of Electrical Engineering, Maulana Azad National Institute of Technology, \\ Bhopal 462003, Madhya Pradesh, India
}

\begin{abstract}
Now a day's solar photovoltaic (PV) system got more attention from researchers as well as the power industry, as the solar has a huge potential and certain advantages over the conventional electrical energy sources such as clean, green and everlasting source of energy. Lots of literature found on solar PV in past few decades. In this paper the behaviour of solar PV is studied with changing environmental conditions i.e. change in solar radiation or insolation, change in temperature and different mismatch conditions such as different insolation or partial shading condition and temperature mismatch of a solar PV array. The detailed simulations as well as experimental results are presented along with the behaviour of solar PV with changing environmental conditions. The analysis may be helpful for researcher of this field.
\end{abstract}

\section{KEYWORDS}

Renewable energy, Solar photovoltaic, Uniform insolation, Partial shading, Mismatch condition, Temperature mismatch.

\section{NOMENCLATURE}

$e \quad$ Electron charge $\left(1.602 \times 10^{-19} \mathrm{C}\right)$

$k \quad$ Boltzmann constant,

$I_{p v} \quad$ Cell output current A

$I_{p h} \quad$ Photon generated current

$I_{s} \quad$ First diode saturation current

$I_{s 2} \quad$ Second diode saturation current

$R_{s} \quad$ Series resistance of cell

$R_{s h} \quad$ Shunt resistance of cell

$V_{p v} \quad$ Cell's output voltage

$V_{T} \quad$ Thermal voltage

$\mathrm{T}_{\text {meas }} \quad$ Cell's Parameter extraction temperature

$P_{M} \quad$ Maximum power obtain from solar PV 
$V_{M} \quad$ PV array's output voltage corresponding to maximum power

$I_{M} \quad$ PV array's output current corresponding to maximum power

$\mathrm{q} \quad$ Charge on an electron

$\mathrm{N} \quad$ Diode emission coefficient or quality factor of the first diode

N2 Diode emission coefficient or quality factor of the second diode

$\mathrm{I}_{\mathrm{r}} \quad$ Irradiance (light intensity or insolation) in $\mathrm{W} / \mathrm{m}^{2}$ falling on the cell

$\mathrm{I}_{\mathrm{ph} 0} \quad$ The measured solar generated current for the Standard Insolation $\mathrm{I}_{\mathrm{r} 0}=1000 \mathrm{~W} / \mathrm{m}^{2}$

$T_{I p h 1} \quad$ First order temperature coefficient for $\mathrm{I}_{\mathrm{ph}}$

$T X_{I s 1} \quad$ Temperature exponent for $\mathrm{I}_{\mathrm{s}}$

$T X_{I s 2} \quad$ Temperature exponent for $\mathrm{I}_{\mathrm{s} 2}$

$T_{R s 1} \quad$ Temperature exponent for $\mathrm{R}_{\mathrm{s}}$

$T_{R s 2} \quad$ Temperature exponent for $\mathrm{R}_{\mathrm{sh}}$

\section{INTRODUCTION}

Now a day's mankind is facing a massive challenge. The overall socio economic growth needs increase in energy demand which requires additional source of energy other than conventional sources of energy. Among many important factors sky-rocketing growth of fossil fuels prices shows that we are approaching the ceiling of oil supply in addition to carbon emission by the conventional energy sources contributing towards global warming. Renewable energies sources like solar and wind energy are the best option to achieve all above requirements [1].

Solar energy is a large source of energy available free of cost, at fairly equal manner. There are two methods to extract the solar energy 1) Solar thermal plants 2) Solar cells i.e. photovoltaic cells. Among wide variety of renewable energy projects in progress the photovoltaic cell (Solar $\mathrm{PV}$ ) is the most promising future energy technology option. The direct conversion of solar radiation to electricity by PV cells has a number of significant advantages as an electricity generator, along with the significant challenges like Energy cost, Energy fluctuation, Location dependence, and Huge investment requirements. The efficiency enhancement is a big issue in reducing cost of PV system since maintenance requirement is very low in PV systems which will lead to the real cost savings. For efficiency improvement it is very necessary to know the behaviour of solar PV with changing environmental condition [2-5].

\section{Modelling OF PV SYSTEM}

Equation (1) governs the characteristics of a solar cell which behaves more like a current source. A solar array is a series and parallel both combinations of solar cell The modelling of solar cell is done as both current and voltage source but the solar cell characteristic is more similar to current source as shown in Figure 1 hence the. Fig (1) gives the modelling of solar cell as current source with two diode model [6-10]. 


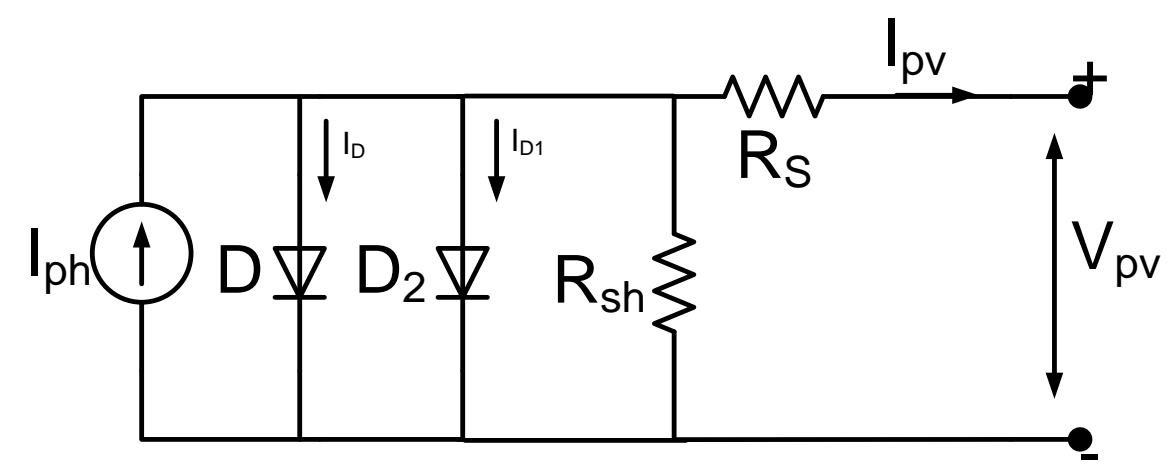

Fig. 1 Electrical equivalent circuit of a PV cell

$$
I_{p v}=I_{p h}-I_{s}\left[\exp \left\{\frac{V_{p v}+I_{p v} R s}{N \times V_{T}}\right\}-1\right]-I_{s_{2}}\left[\exp \left\{\frac{V_{p v}+I_{p v} R_{s}}{N_{2} \times V_{T}}\right\}-1\right]-\frac{V_{p v}+I_{p v} R_{s}}{R_{s h}}
$$

\subsection{Dependency on solar radiation or insolation:}

Figure 5 shows the dependency of characteristic on variation in insolation 5 . The photon generated current $\left(\mathrm{I}_{\mathrm{ph}}\right)$ of the solar cell is the function of insolation as given in equation (2) and increases proportionally with increase in insolation. Figure 6 reflects that the maximum power also varies with respect to changing insolation [11].

Solar induced current or photon generated current $I_{p h}$ is given by

$$
I_{p h}=I_{p h 0} \frac{I_{r}}{I_{r 0}}
$$

\subsection{Dependency on temperature:}

Temperature is one another factor which shows influence on solar cell's characteristic. Equation (3) reflects the relationship between photon generated of solar PV characteristic and temperature. Equation (4) and (5) gives the relationship between saturation current of diode and temperature [11].

$$
\begin{gathered}
I_{p h} T=I_{p h} 1+T_{I p h 1}\left(T-T_{\text {meas }}\right) \ldots . . \\
I_{s}(T)=I_{s}\left(\frac{T}{T_{\text {meas }}}\right)^{\frac{T X_{I s 1}}{N}} \exp \frac{E G\left(\frac{T}{T_{\text {meas }}}-1\right)}{N V_{T}} . .
\end{gathered}
$$


Electrical and Electronics Engineering: An International Journal (ELELIJ) Vol 4, No 3, August 2015

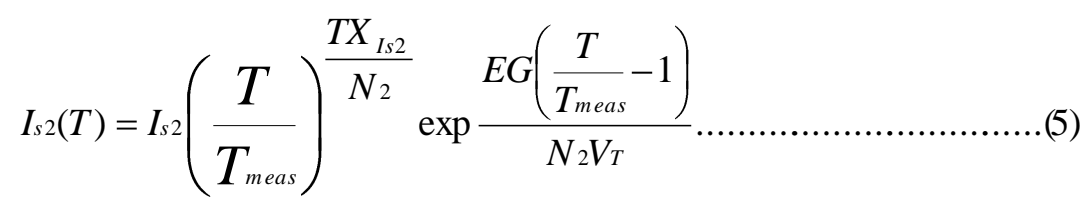

The relation between series and shunt resistance of solar cell is given in equation (6) and (7).

$$
\begin{gathered}
R_{s}(T)=R_{s}\left(\frac{T}{T_{\text {meas }}}\right)^{T_{R s 1}} \\
R_{s h}(T)=R_{s h}\left(\frac{T}{T_{\text {meas }}}\right)^{T_{R s 2}}
\end{gathered}
$$

\section{Simulation AND EXPERIMENTAL RESUlTS}

Solar module TBP1210M made by Tata BP Solar India Limited are used for experimental analysis and the simulations are conducted with the parameters of module given in datasheet [13]. Simulation is done in the SIMSCAPE library of MATLAB which deals with physical signal in place of unit less signal as used in simulink library of MATLAB.

Figure 2 shows the experimental setup to verify the characteristic of solar PV with changing environmental conditions and mismatch condition.

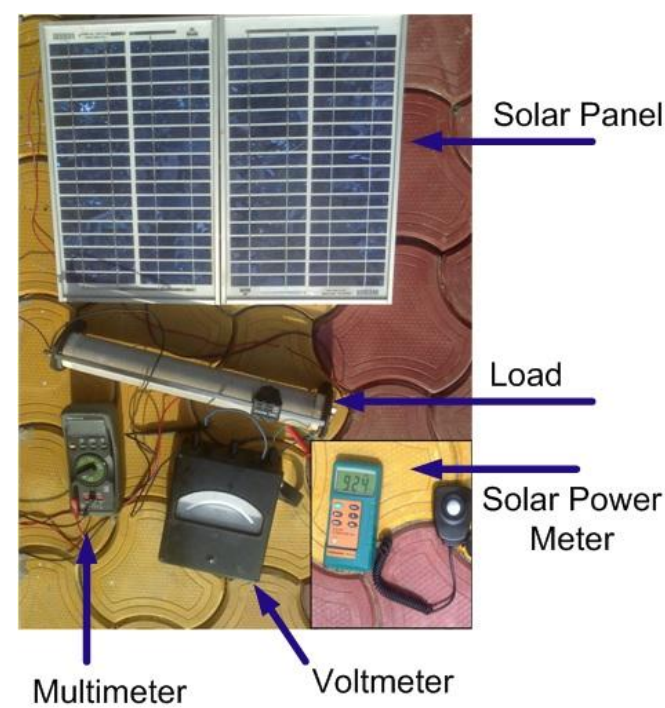

Fig. 2. Experimental setup

Figure 3 shows the current versus voltage (I-V) characteristic and figure 4 shows the power versus voltage $(\mathrm{P}-\mathrm{V})$ characteristic of solar cell at constant insolation $1000 \mathrm{~W} / \mathrm{m}^{2}$ and constant temperature $25^{\circ} \mathrm{C}$ 
Electrical and Electronics Engineering: An International Journal (ELELIJ) Vol 4, No 3, August 2015

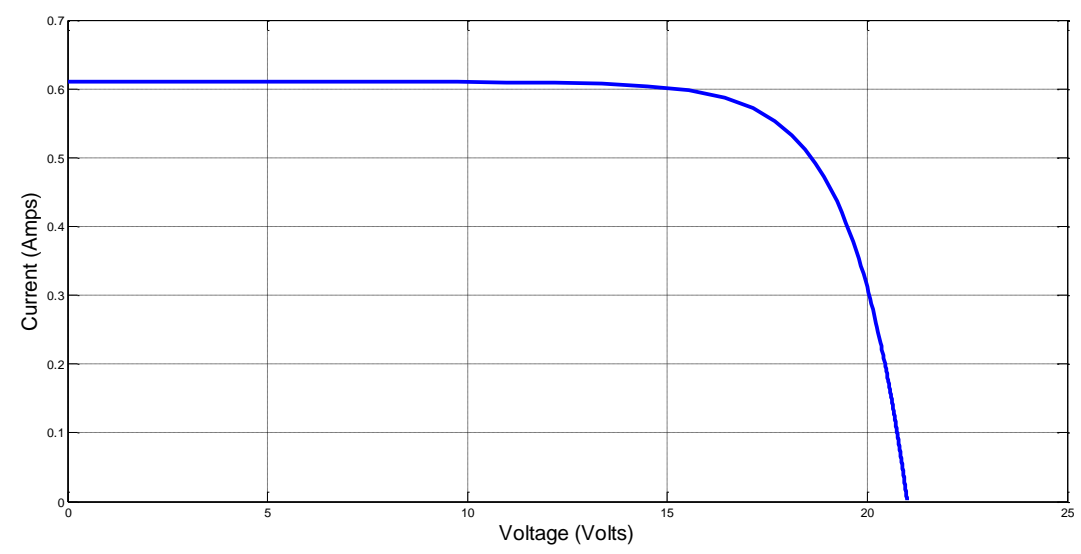

Fig. 3. I-V characteristic solar PV module at $1000 \mathrm{~W} / \mathrm{m}^{2}$ insolation and $25^{\circ} \mathrm{C}$ temperature

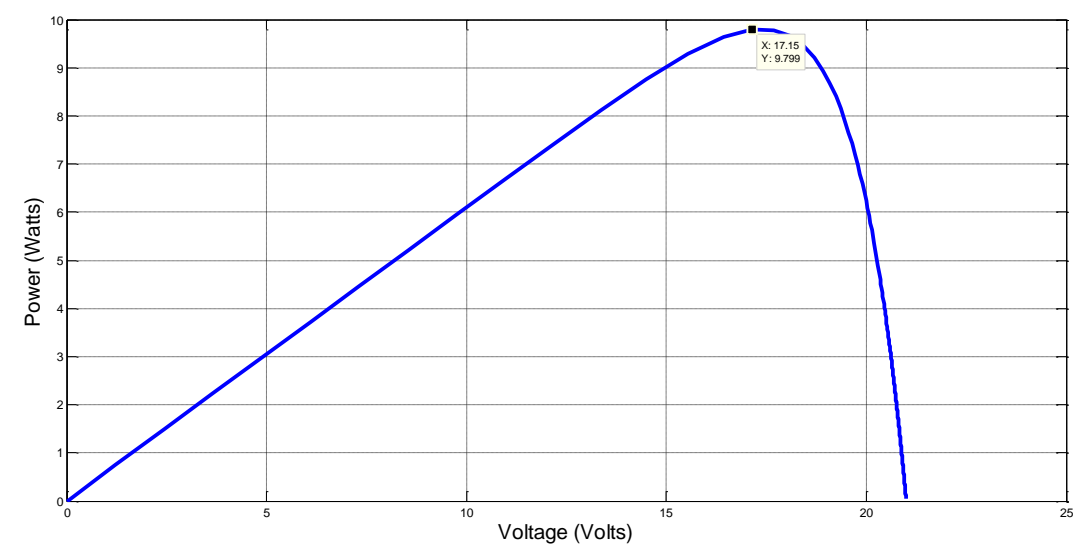

Fig. 4. P-V characteristic solar PV module at $1000 \mathrm{~W} / \mathrm{m}^{2}$ insolation and $25^{\circ} \mathrm{C}$ temperature

Analysis of waveforms is presented in Table I given below:

TABLE I RESULTS FOR CONSTANT INSOLATION AND TEMPERATURE

\begin{tabular}{|l|l|l|l|l|l|}
\hline Solar Panel & Insolation $\left(\mathrm{W} / \mathrm{m}^{2}\right)$ & Temperature $\left({ }^{0} \mathrm{C}\right)$ & $\mathrm{P}_{\mathrm{M}}(\mathrm{W})$ & $\mathrm{V}_{\mathrm{M}}(\mathrm{V})$ & $\mathrm{I}_{\mathrm{M}}(\mathrm{A})$ \\
\hline TBP1210M & 1000 & 25 & 9.799 & 17.15 & 0.5715 \\
\hline
\end{tabular}

\subsection{Effect of insolation on solar PV characteristic}

Figure 5 shows the I-V characteristic and figure 6 shows the P-V characteristic of solar panel at variable insolation and at constant temperature $25^{\circ} \mathrm{C}$ 
Electrical and Electronics Engineering: An International Journal (ELELIJ) Vol 4, No 3, August 2015

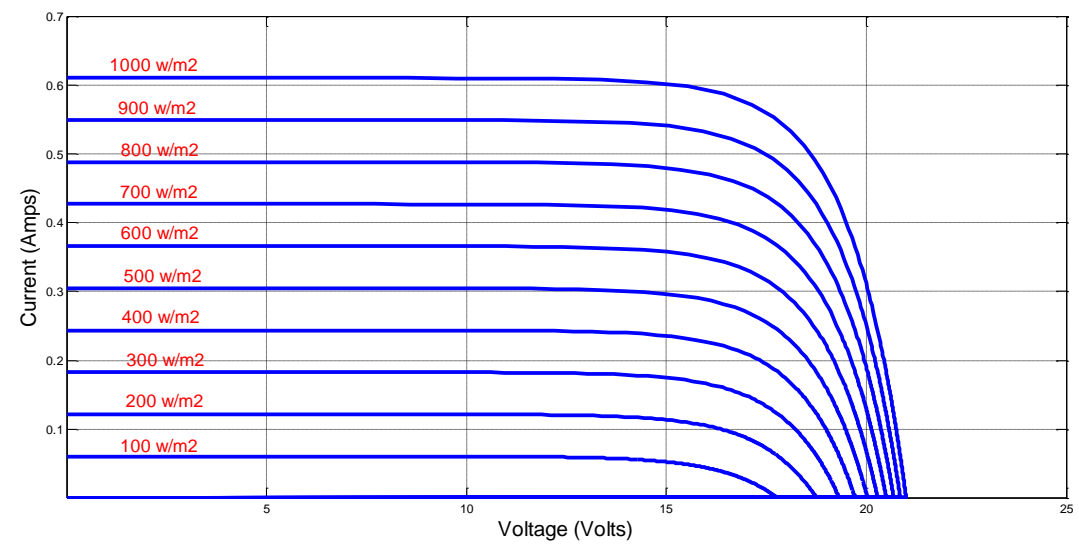

Fig. 5. I-V characteristic of solar PV at variable insolation and at constant temperature $25^{\circ} \mathrm{C}$

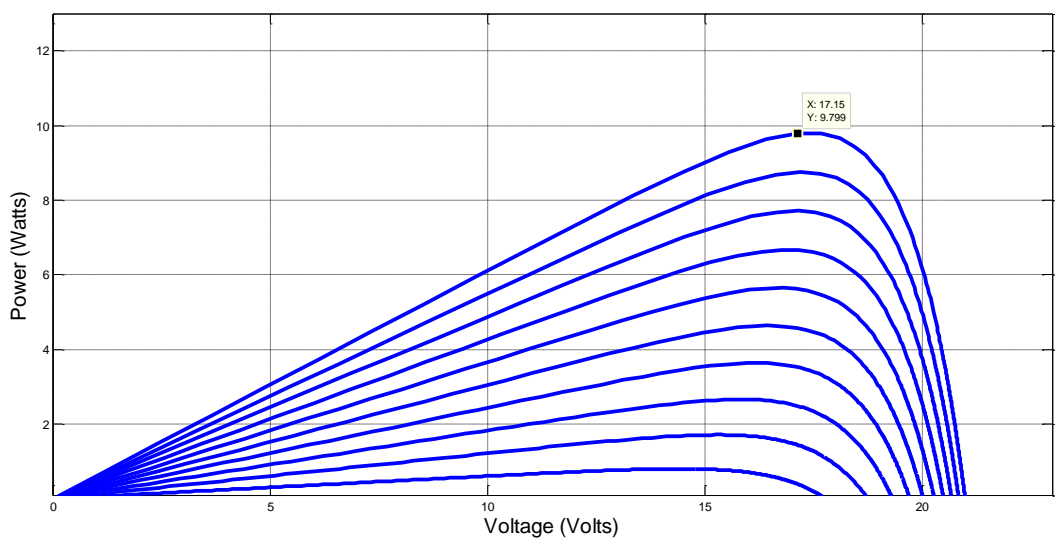

Fig. 6. P-V characteristic of solar PV at variable insolation and at constant temperature $25^{\circ} \mathrm{C}$

Analysis of waveforms is presented in Table II given below:

Table Ii Results for Constant Temperature and Variable Insolation

\begin{tabular}{|l|l|l|l|l|l|}
\hline Solar Panel & Insolation $\left(\mathrm{W} / \mathrm{m}^{2}\right)$ & Temperature $\left({ }^{0} \mathrm{C}\right)$ & $\mathrm{P}_{\mathrm{M}}(\mathrm{W})$ & $\mathrm{V}_{\mathrm{M}}(\mathrm{V})$ & $\mathrm{I}_{\mathrm{M}}(\mathrm{A})$ \\
\hline TBP1210M & 1000 & 25 & 9.799 & 17.15 & 0.5715 \\
\hline TBP1210M & 900 & 25 & 8.756 & 17.21 & 0.5087 \\
\hline TBP1210M & 800 & 25 & 7.709 & 17.16 & 0.4493 \\
\hline TBP1210M & 700 & 25 & 6.671 & 16.78 & 0.3976 \\
\hline TBP1210M & 600 & 25 & 5.648 & 16.80 & 0.3361 \\
\hline TBP1210M & 500 & 25 & 4.637 & 16.44 & 0.2820 \\
\hline TBP1210M & 400 & 25 & 3.640 & 16.23 & 0.2243 \\
\hline TBP1210M & 300 & 25 & 2.663 & 15.82 & 0.1683 \\
\hline TBP1210M & 200 & 25 & 1.713 & 15.26 & 0.1122 \\
\hline TBP1210M & 100 & 25 & 0.803 & 14.45 & 0.0555 \\
\hline
\end{tabular}


Electrical and Electronics Engineering: An International Journal (ELELIJ) Vol 4, No 3, August 2015

\subsection{Effect of temperature on solar PV characteristic}

Figure 7 shows the I-V characteristic and figure 8 shows the P-V characteristic of solar panel at constant insolation $1000 \mathrm{~W} / \mathrm{m}^{2}$ and at different temperature

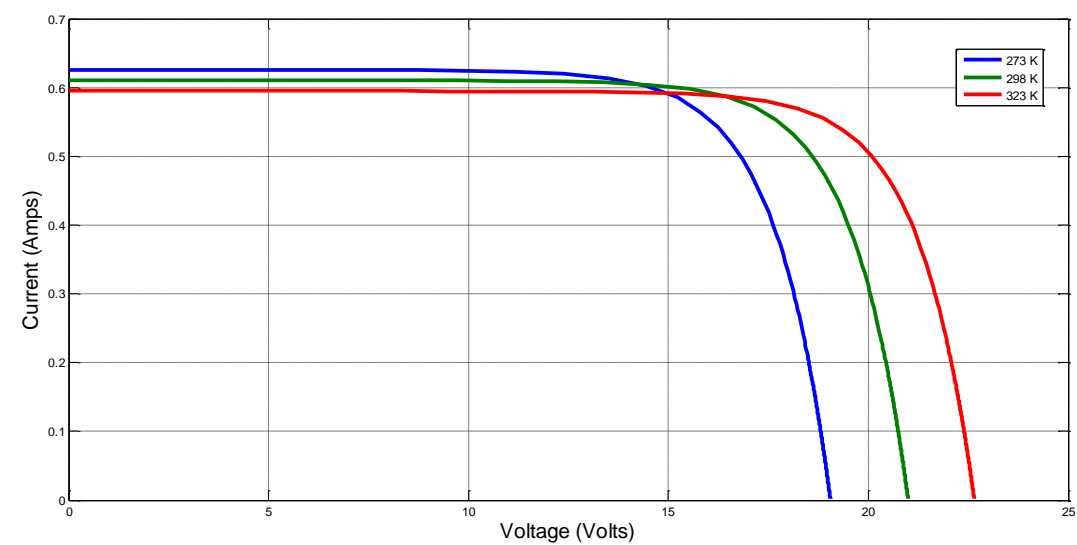

Fig. 7. I-V characteristic of solar PV at constant insolation $1000 \mathrm{~W} / \mathrm{m}^{2}$ and at different temperature

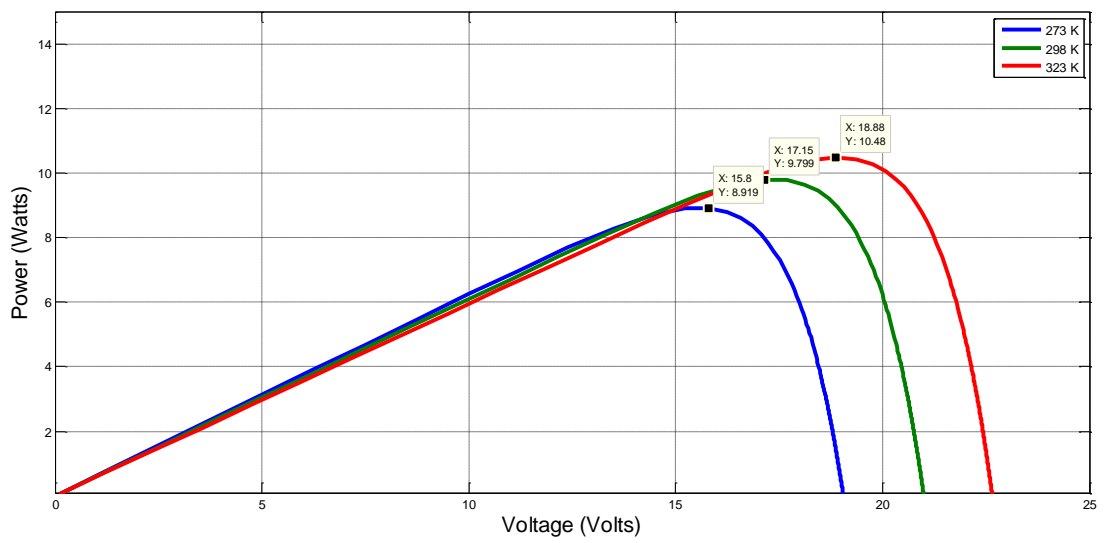

Fig. 8. P-V characteristic of solar PV at constant insolation $1000 \mathrm{~W} / \mathrm{m}^{2}$ and at different temperature

Analysis of waveforms is presented in Table III given below:

Table Iii Results for Constant Insolation and Variable Temperature

\begin{tabular}{|l|l|l|l|l|l|}
\hline Solar Panel & Insolation $\left(\mathrm{W} / \mathrm{m}^{2}\right)$ & Temperature $\left({ }^{0} \mathrm{C}\right)$ & $\mathrm{P}_{\mathrm{M}}(\mathrm{W})$ & $\mathrm{V}_{\mathrm{M}}(\mathrm{V})$ & $\mathrm{I}_{\mathrm{M}}(\mathrm{A})$ \\
\hline TBP1210M & 1000 & 00 & 8.919 & 15.80 & 0.5644 \\
\hline TBP1210M & 1000 & 25 & 9.799 & 17.15 & 0.5715 \\
\hline TBP1210M & 1000 & 50 & 10.48 & 18.88 & 0.5552 \\
\hline
\end{tabular}

\subsection{Effect of mismatch condition}

Mismatch condition of a solar PV array is nothing but the mismatch in either insolation or in working temperature of solar panels connected in a large array either in series or in parallel. In series connection voltage of connected panels are added and the current should be same similarly in parallel connection voltage should be same and the current of each panel is added. 


\subsubsection{Mismatch in solar insolation}

In a large PV array, insolation mismatch is a common condition. It may be due to the partial shading or shadow.

A. Mismatch in solar insolation for series connection

For performance analysis two series connected solar modules are taken, mismatch in isolation can be better understand by considering an example: if first solar module receives solar insolation of $1000 \mathrm{~W} / \mathrm{m}^{2}$ and second receives solar insolation of $400 \mathrm{~W} / \mathrm{m}^{2}$ as shown in figure 9 .

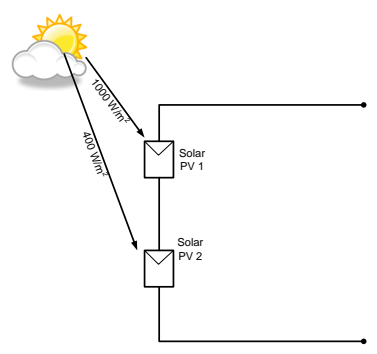

Fig. 9. Condition of insolation mismatch or partial shading.

Figure 10 shows the I-V characteristic and figure 11 shows the P-V characteristic of solar panel at constant temperature and at mismatched insolation of $1000 \mathrm{~W} / \mathrm{m}^{2}$ and $400 \mathrm{~W} / \mathrm{m}^{2}$. This mismatch may occur when modules are partially shaded. In large solar PV arrays this condition of partial shading is common.

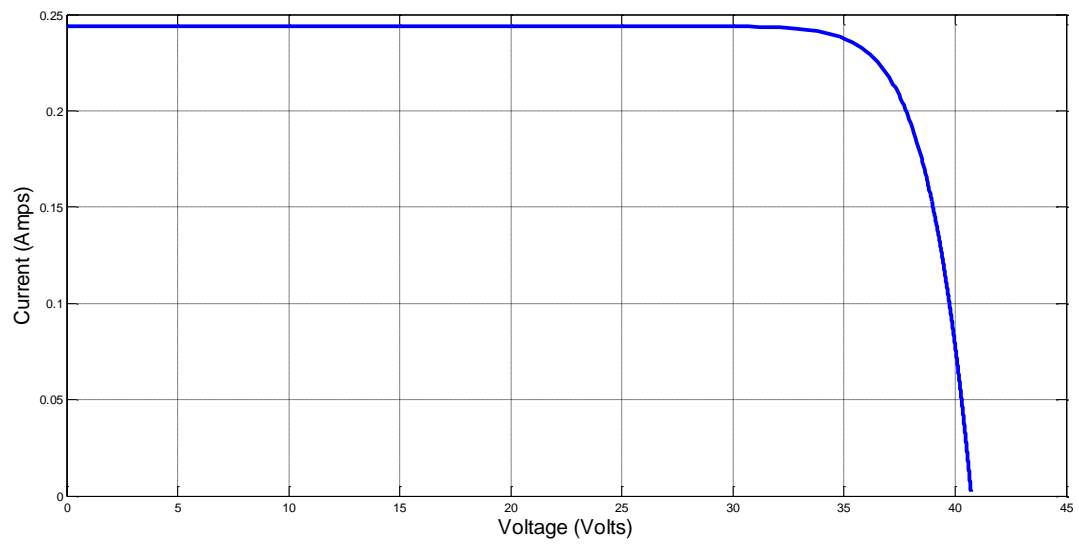

Fig. 10. I-V characteristic of solar array for condition of insolation mismatch or partial shading. 


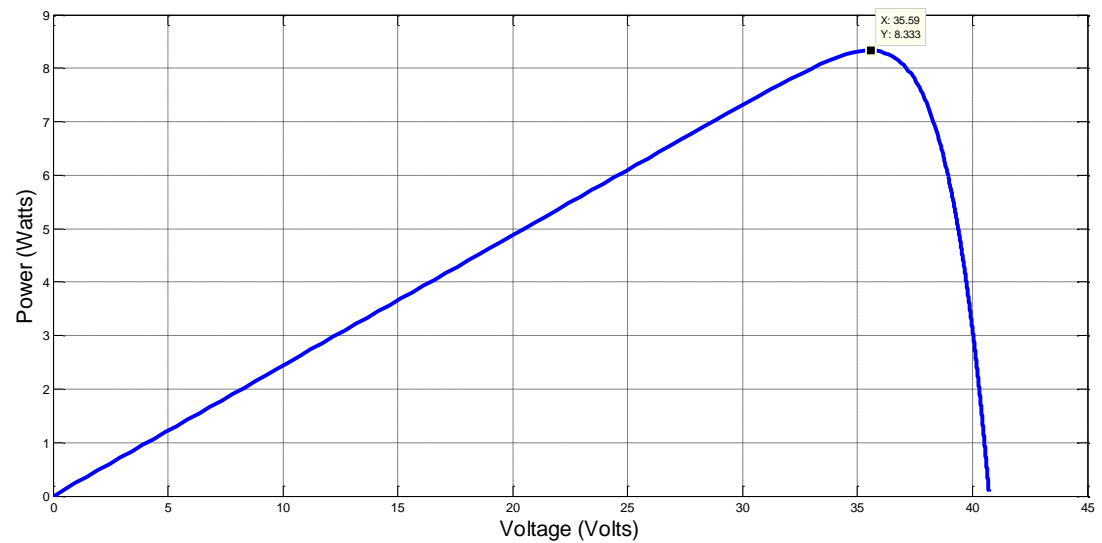

Fig. 11. P-V characteristic of solar array for condition of insolation mismatch or partial shading.

Analysis of waveforms is presented in Table IV given below:

Table Iv Results for Insolation Mismatch Condition (Series)

\begin{tabular}{|l|l|l|l|l|l|}
\hline Solar Array & Insolation $\left(\mathrm{W} / \mathrm{m}^{2}\right)$ & Temperature $\left({ }^{0} \mathrm{C}\right)$ & $\mathrm{P}_{\mathrm{M}}(\mathrm{W})$ & $\mathrm{V}_{\mathrm{M}}(\mathrm{V})$ & $\mathrm{I}_{\mathrm{M}}(\mathrm{A})$ \\
\cline { 1 - 5 } 1. TBP1210M & 1000 & 25 & 8.33 & 35.59 & 0.2341 \\
\cline { 1 - 4 } 2. TBP1210M & 400 & & & & \\
\hline
\end{tabular}

In insolation mismatch condition power out from the array is less because of the shaded (400 $\mathrm{W} / \mathrm{m}^{2}$ ) panel's current dominating the other panel's current as they both are connected in series. For eliminating this effect bypass diode mitigation technique is found in literature [14]. Figure 12 shows the diode mitigation technique used to draw more power in mismatched insolation or partial shading condition.

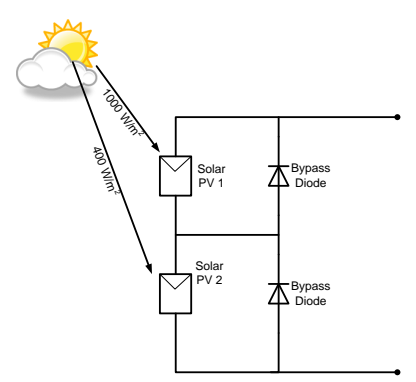

Fig. 12. Diode mitigation technique for condition of insolation mismatch or partial shading.

Using diode mitigation technique Figure 13 shows the I-V characteristic and figure 14 shows the $\mathrm{P}-\mathrm{V}$ characteristic of solar PV. 
Electrical and Electronics Engineering: An International Journal (ELELIJ) Vol 4, No 3, August 2015

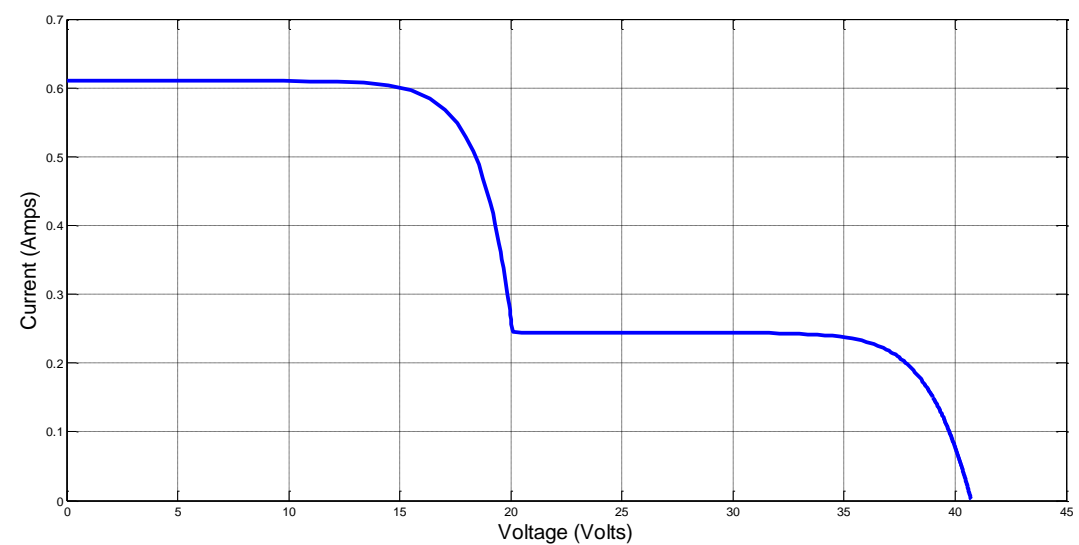

Fig. 13. I-V characteristic of solar PV with diode mitigation technique for condition of insolation mismatch or partial shading.

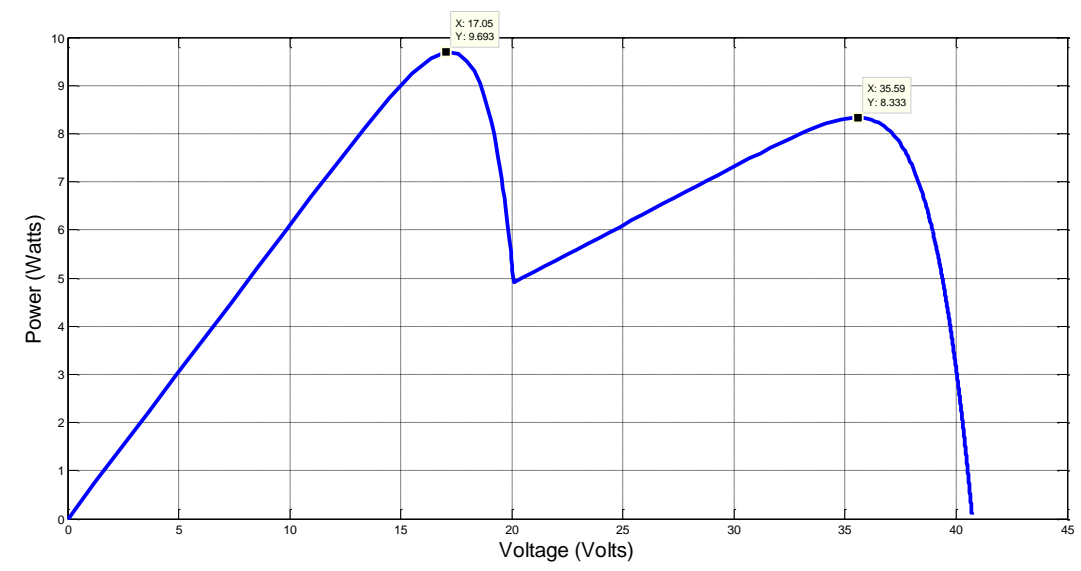

Fig. 14. P-V characteristic of solar PV with diode mitigation technique for condition of insolation mismatch or partial shading.

Analysis of waveforms is presented in Table V given below:

Table V Results For Insolation Mismatch Condition (Series) With Diode Mitigation Technique

\begin{tabular}{|l|l|l|l|l|l|}
\hline Solar Array & Insolation $\left(\mathrm{W} / \mathrm{m}^{2}\right)$ & Temperature $\left({ }^{0} \mathrm{C}\right)$ & $\mathrm{P}_{\mathrm{M}}(\mathrm{W})$ & $\mathrm{V}_{\mathrm{M}}(\mathrm{V})$ & $\mathrm{I}_{\mathrm{M}}(\mathrm{A})$ \\
\hline 1. TBP1210M & 1000 & 25 & 9.693 & 17.05 & 0.5684 \\
\cline { 1 - 5 } 2. TBP1210M & 400 & & & & \\
\hline
\end{tabular}

B. Mismatch in solar insolation for parallel connection

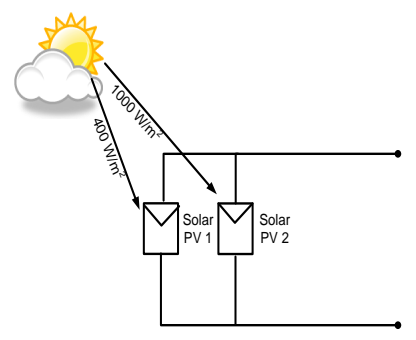

Fig. 15. Condition of insolation mismatch or partial shading for parallel connection 


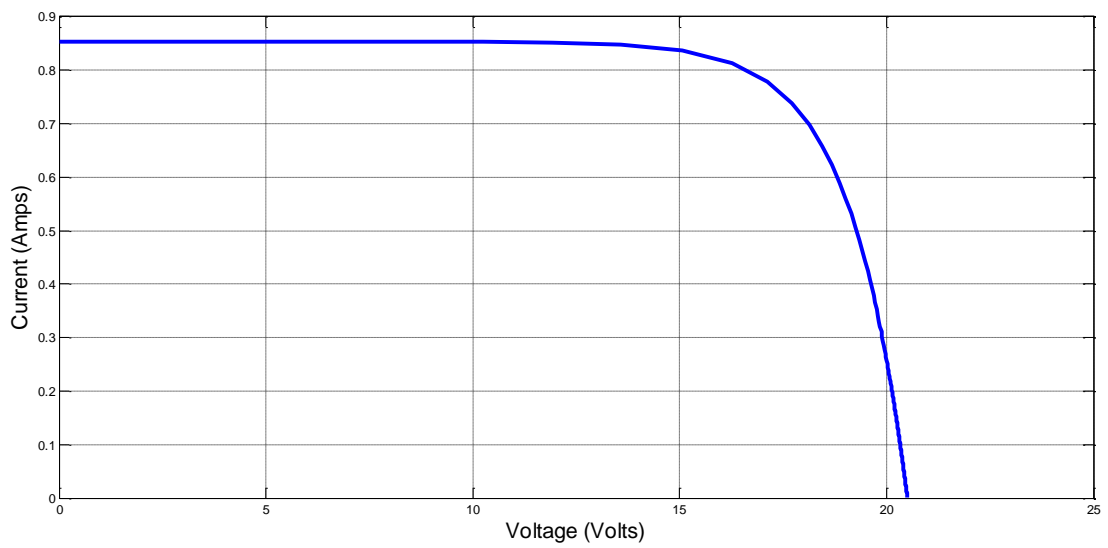

Fig. 16. I-V characteristic of solar array for condition of insolation mismatch or partial shading.

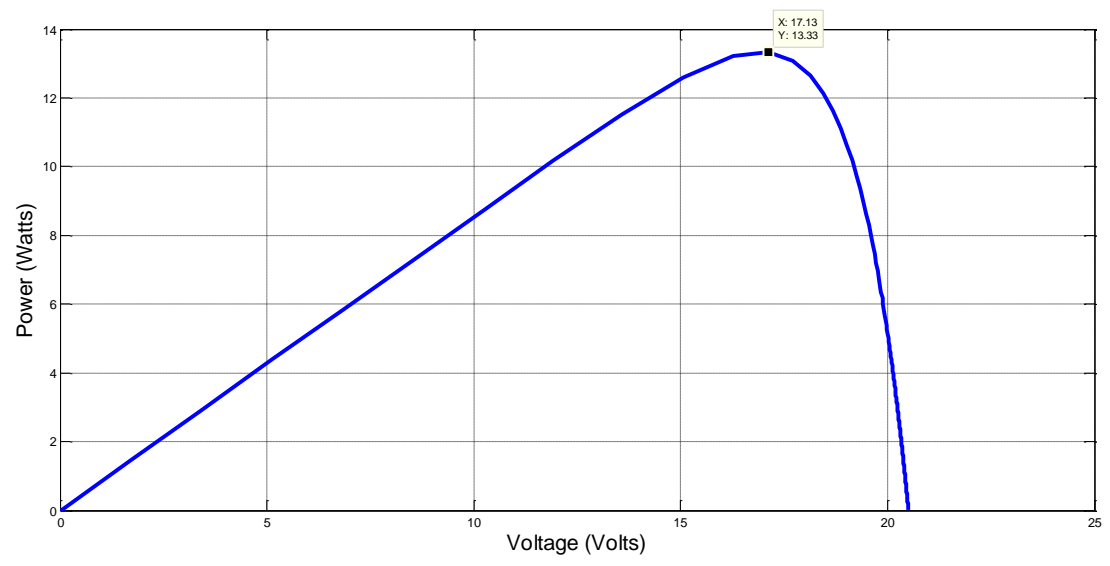

Fig. 17. P-V characteristic of solar array for condition of insolation mismatch or partial shading .

Analysis of waveforms is presented in Table VI given below:

Table Vi Results for Insolation Mismatch Condition (Parallel)

\begin{tabular}{|l|l|l|l|l|l|}
\hline Solar Array & Insolation $\left(\mathrm{W} / \mathrm{m}^{2}\right)$ & Temperature $\left({ }^{0} \mathrm{C}\right)$ & $\mathrm{P}_{\mathrm{M}}(\mathrm{W})$ & $\mathrm{V}_{\mathrm{M}}(\mathrm{V})$ & $\mathrm{I}_{\mathrm{M}}(\mathrm{A})$ \\
\hline 1. TBP1210M & 1000 & 25 & 13.33 & 17.13 & 0.7785 \\
\cline { 1 - 5 } 2. TBP1210M & 400 & & & & \\
\hline
\end{tabular}

Insolation variation affects the short circuit current of solar PV hence in the case of series connected modules the power out from the solar array is less in insolation mismatch condition as given in Table IV and Table V. While connected in parallel power output is greater as given in Table VI, this is because in parallel connection current is added.

\subsubsection{Mismatch in temperature}

One another mismatch condition is possible in large PV array is temperature difference in different solar panels. This temperature mismatch condition can be understand by taking an example of two panels with different temperatures i.e. $50^{\circ} \mathrm{C}$ and $25^{\circ} \mathrm{C}$. This may be caused due to partial raining or temperature variation in large area. With increase in temperature open circuit voltage increases proportionally and short circuit current decreases logarithmically. 
Electrical and Electronics Engineering: An International Journal (ELELIJ) Vol 4, No 3, August 2015

\section{A. Mismatch in temperature for series connection}

Figure 18 depicts the condition of temperature mismatch when two or more modules of an array work at the different temperature.

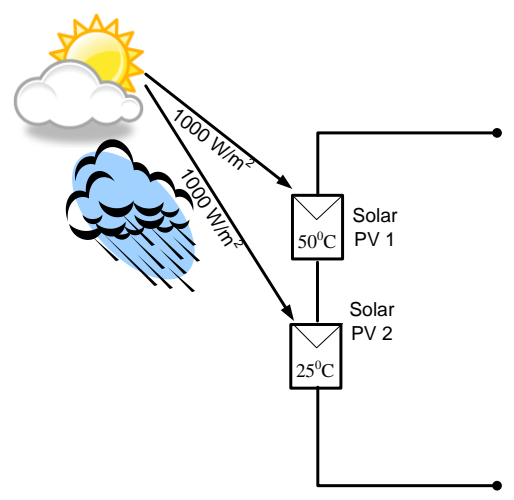

Fig. 18. Condition of temperature mismatch or partial raining condition.

With change in temperature current changes slightly while the voltage changes proportionally hence in series connection the power output is slightly reduced. Because the changed voltage is added in series connection.

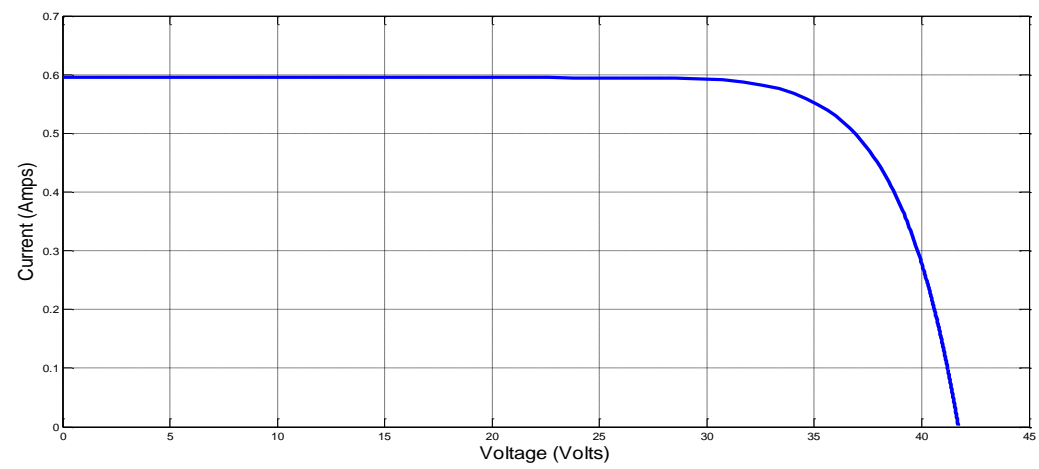

Fig. 19. I-V characteristic of solar array for condition of temperature mismatch or partial raining.

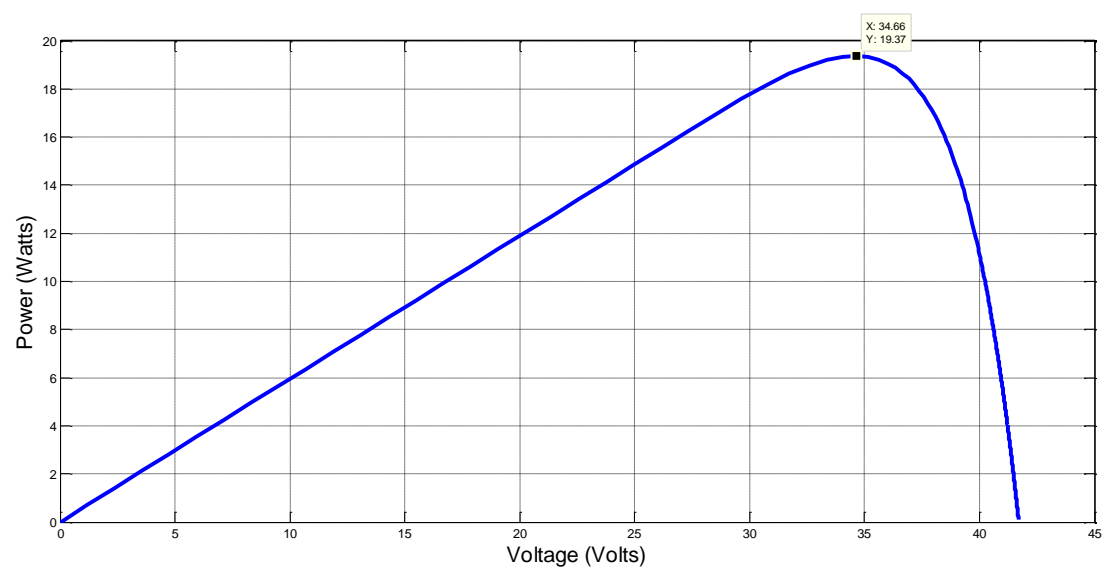

Fig. 20. P-V characteristic of solar array for condition of temperature mismatch or partial raining. 
Electrical and Electronics Engineering: An International Journal (ELELIJ) Vol 4, No 3, August 2015

Analysis of waveforms is presented in Table VII given below:

\begin{tabular}{|l|l|l|l|l|l|}
\hline Solar Array & Insolation $\left(\mathrm{W} / \mathrm{m}^{2}\right)$ & Temperature $\left({ }^{0} \mathrm{C}\right)$ & $\mathrm{P}_{\mathrm{M}}(\mathrm{W})$ & $\mathrm{V}_{\mathrm{M}}(\mathrm{V})$ & $\mathrm{I}_{\mathrm{M}}(\mathrm{A})$ \\
\hline 1. TBP1210M & 1000 & 25 & 19.37 & 34.66 & 0.559 \\
\cline { 1 - 3 } 2. TBP1210M & 1000 & 50 & & & \\
\hline
\end{tabular}

After applying diode mitigation technique there is slight change in solar output current is observed because with change in temperature the main effect is on open circuit voltage of solar PV.

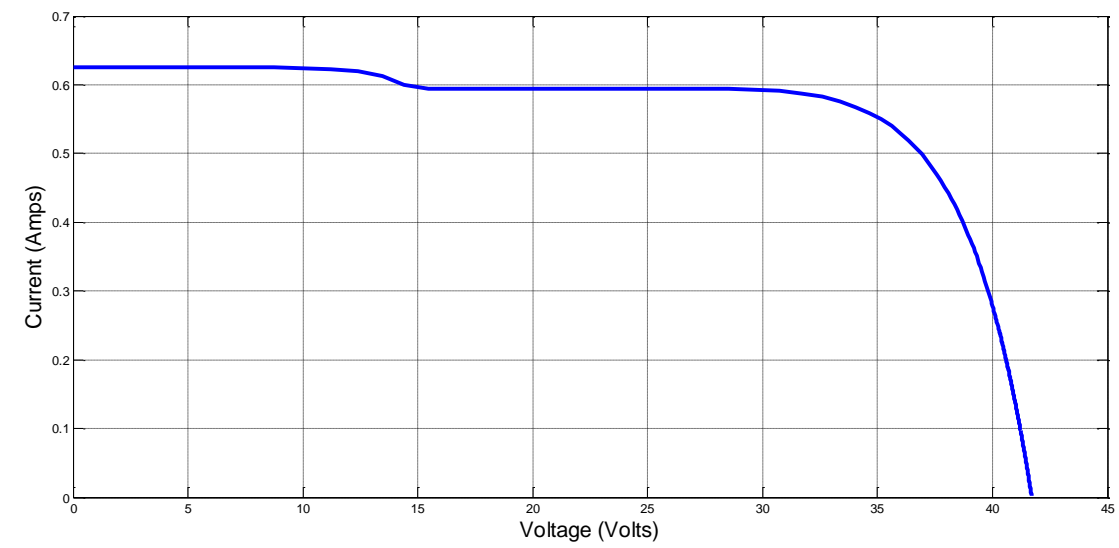

Fig. 21. I-V characteristic of solar array with diode mitigation technique for condition of temperature mismatch or partial raining.

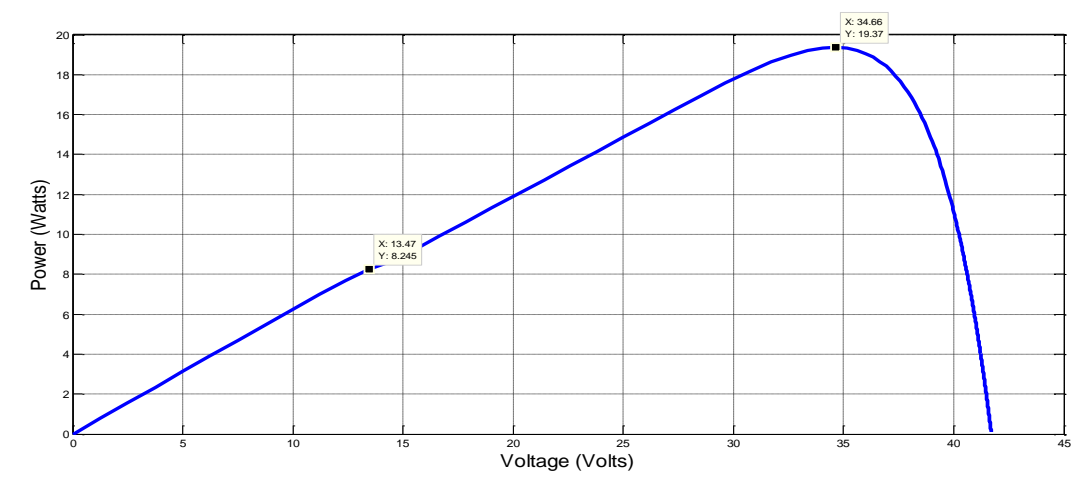

Fig. 22. PV characteristic of solar array with diode mitigation technique for condition of temperature mismatch or partial raining.

Analysis of waveforms is presented in Table VII given below:

Table Vii Results For Temperature Mismatch Condition (Series) With Diode Mitigation Technique

\begin{tabular}{|l|l|l|l|l|l|}
\hline Solar Array & Insolation $\left(\mathrm{W} / \mathrm{m}^{2}\right)$ & Temperature $\left({ }^{0} \mathrm{C}\right)$ & $\mathrm{P}_{\mathrm{M}}(\mathrm{W})$ & $\mathrm{V}_{\mathrm{M}}(\mathrm{V})$ & $\mathrm{I}_{\mathrm{M}}(\mathrm{A})$ \\
\hline 1. TBP1210M & 1000 & 25 & 19.37 & 34.66 & 0.559 \\
\cline { 1 - 3 } 2. TBP1210M & 1000 & 50 & & & \\
\hline
\end{tabular}




\section{B. Mismatch in temperature for parallel connection}

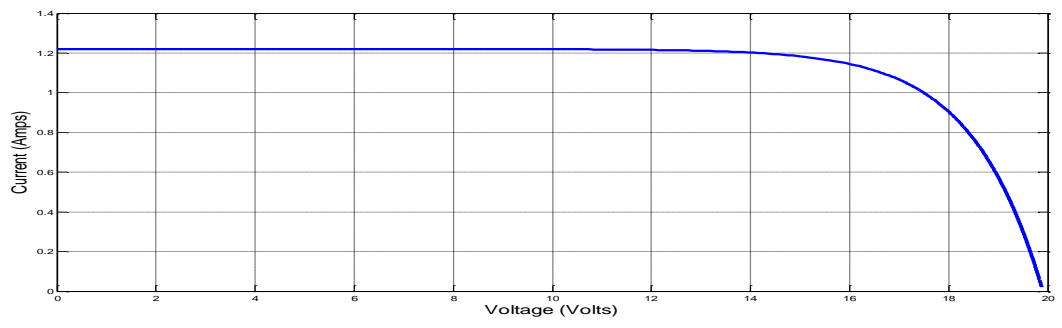

Fig. 23. I-V characteristic of solar array for condition of temperature mismatch or partial raining.

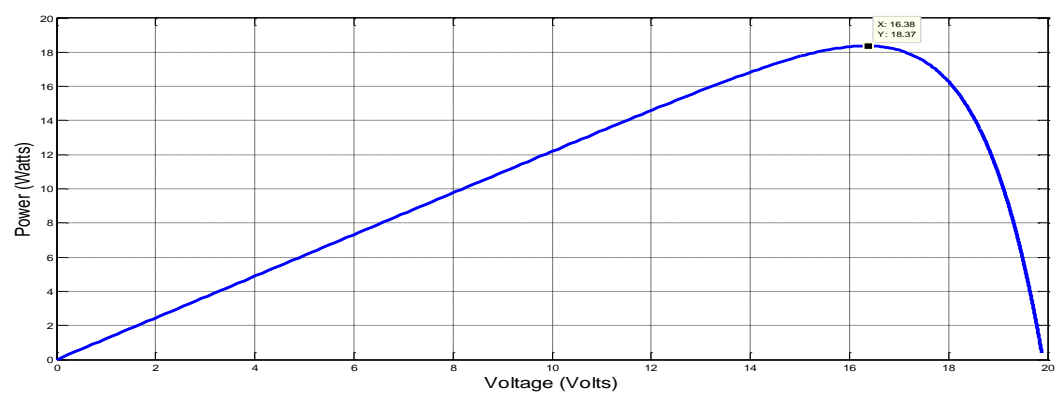

Fig. 24. P-V characteristic of solar array for condition of temperature mismatch or partial raining.

Table Vi Results For Temperature Mismatch Condition (Parallel)

\begin{tabular}{|l|l|l|l|l|l|}
\hline Solar Array & Insolation $\left(\mathrm{W} / \mathrm{m}^{2}\right)$ & Temperature $\left({ }^{0} \mathrm{C}\right)$ & $\mathrm{P}_{\mathrm{M}}(\mathrm{W})$ & $\mathrm{V}_{\mathrm{M}}(\mathrm{V})$ & $\mathrm{I}_{\mathrm{M}}(\mathrm{A})$ \\
\hline 1. TBP1210M & 1000 & 25 & 18.37 & 16.38 & 1.122 \\
\cline { 1 - 3 } 2. TBP1210M & 400 & 50 & & & \\
\hline
\end{tabular}

\section{Conclusion}

The behaviour of solar PV with changing environmental condition as well as mismatch condition is optimized in this paper from MATLAB simulation in SIMSCAPE and through experimental validation. Lots of research is going on efficiency improvement of solar PV system. This paper helps the researcher of this field to understand the characteristic behaviour of solar PV with changing environmental and mismatch condition, also gives a novel idea to research in the direction of temperature mismatch condition while modules are connected in parallel. A significant amount of power loss occurs in this case due to voltage difference in parallel connected modules. Researcher can take this problem to find the solution which can help them doing their research work. 


\section{REFERENCES}

[1] Chetan Singh Solanki "Solar Photovoltaics: Fundamental, Technology and application" Second Edition-2011, Book Published by: PHI Learning Private Ltd., New Delhi

[2] Nema Savita, R. K. Nema, Gayatri Agnihotri. MATLAB/Simulink based study of photovoltaic cells/modules/array and their experimental verification. International journal of Energy and Environment 2010;1.3:500-487.

[3] Nema R K, Savita Nema, Gayatri Agnihotri. Computer simulation based study of photovoltaic cells/modules and their experimental verification. International Journal of Recent Trends in Engineering 2009;1.3:156-151.

[4] Nema R K, Savita Nema, Gayatri Agnihotri. Design, development and simulation of PC-based scheme for characterisation of solar photovoltaic modules. International Journal of Power Electronics 2010;2.3:325-304.

[5] Nema R K, Savita Nema, Gayatri Agnihotri. Determination of IV Characteristics of Solar Photovoltaic Module by Computer Controlled Loading. Proceedings of the 15th International Photovoltaic Science \& Engineering Conference (PVSEC-15) 2005.

[6] Nikhil Kumar, Suresh K Gawre, Deepak Verma, "Physical Design and Modeling of 24v/48v dc-dc boost converter for solar PV application by using SIMSCAPE library in MATLAB", International Journal of Applied Control, Electrical and Electronics Engineering (IJACEEE), Wireilla Publication, Australia, Vol. 2., No. 2., May, 2014.

[7] Nikhil Kumar, Suresh K Gawre, Deepak Verma, "Harmonics Mitigation of P\&O MPPT Based Solar Powered Neutral Point Clamped Multilevel Inverter", International Journal of Applied Control, Electrical and Electronics Engineering (IJACEEE), Wireilla Publication, Australia, Vol. 2., No. 3., june, 2014.

[8] Nikhil Kumar, Suresh K Gawre, Deepak Verma, "Modeling and Simulation of Neutral point clamped Multilevel Inverter For Solar photovoltaic System", IEEE International Conference on Advances in Engineering and Technology, Nagapattinam, Tamil Nadu, 02-03 May, 2014.

[9] Nikhil Kumar, Suresh K Gawre, Deepak Verma , "Modeling and Simulation of Solar Photovoltaic System and Interfacing with Neutral Point clamped Multilevel Inverter", International Conference in Electrical, Electronics and Computer Science (ICEECS-2014), Chennai, Tamil Nadu, 30 March

[10] Dash, S.K.; Verma, D.; Nema, S.; Nema, R.K., "Comparative analysis of maximum power point (MPP) tracking techniques for solar PV application using MATLAB simulink," IEEE- Recent Advances and Innovations in Engineering (ICRAIE), 2014, vol., no., pp.1,7, 9-11 May 2014

[11] MATLAB Help "SimElectronics/Blocks/Sources/Solar cell"

[12] Gow, J.A. and C.D. Manning. "Development of a Photovoltaic Array Model for Use in PowerElectronics Simulation Studies." IEE Proceedings of Electric Power Applications, Vol. 146, No. 2, pp. 193-200, March 1999.

[13] Tata Power solar, "Solar http://www.tatapowersolar.com/".

[14] Kamarzaman, Nur Atharah, Chee Wei Tan. A comprehensive review of maximum power point tracking algorithms for photovoltaic systems. Renewable and Sustainable Energy Reviews 2014;37:598-585.

\section{AUTHORS}

Deepak Verma was born in Betul, Madhya Pradesh State, India in 1986. He received the B.E. degree from Rajiv Gandhi Technical University, Bhopal, India, in 2008, in electrical and electronics engineering, and the M. Tech. degree in power system from the Maulana Azad National Institute of Technology Bhopal, India in 2010. Currently, he is working toward the $\mathrm{Ph} . \mathrm{D}$. degree in maximum power point tracking of solar photovoltaic system at the Maulana Azad National Institute of Technology Bhopal, India. His research interest includes Solar Photovoltaic, MPTT, Grid interconnection of renewable energy and residential photovoltaic

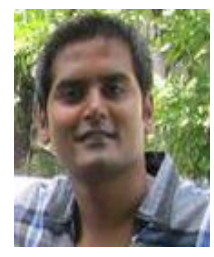
energy storage system. 
Electrical and Electronics Engineering: An International Journal (ELELIJ) Vol 4, No 3, August 2015

Dr. Savita Nema received BE degree in Electrical (1990), M.E. degree in Control System (1994) from RDVV, Jabalpur, India and Ph.D. degree (2011) from RGPV Bhopal, India. She is a professor with the Department of Electrical Engineering, Maulana Azad National Institute of Technology, Bhopal, India. Her research interest includes Renewable Energy, maximum power point tracking in solar PV systems and Control Systems.

Dr. Arun M. Shandilya received BE degree (Electrical Engineering) and M. Tech. degree (Integrated Power Systems) from Nagpur University. PhD degree (1989) from University of Roorkee, India. Since 1979 he is with Maulana Azad National Institute of Technology (earlier MACT), Bhopal in various positions. Currently he is Professor in the department of Electrical Engineering and coordinator TEQIP II. His research interest includes Power System Analysis and Power System protection.

Soubhagya Kumar Dash received BE degree in Electrical Engineering (2005) from BPUT, Raurkela, India, M. Tech. degree in Electrical Drives (2011) from the Maulana Azad National Institute of Techn ology Bhopal, India. Currently, he is working toward the $\mathrm{Ph} . \mathrm{D}$. degree in maximum power point tracking in partial shaded condition at the Maulana Azad National Institute of Technology Bhopal, India.
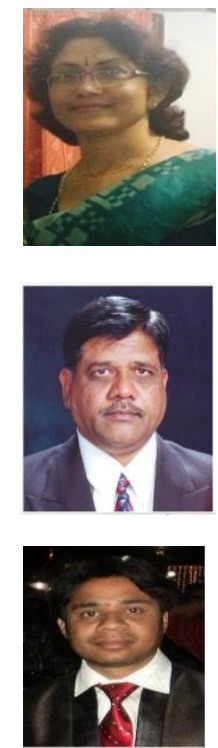